NBER WORKING PAPER SERIES

\title{
SUPPLY CAPACITY, VERTICAL SPECIALIZATION AND TARIFF RATES: THE IMPLICATIONS FOR AGGREGATE U.S. TRADE FLOW EQUATIONS
}

\author{
Menzie D. Chinn \\ Working Paper 11719 \\ http://www.nber.org/papers/w11719 \\ NATIONAL BUREAU OF ECONOMIC RESEARCH \\ 1050 Massachusetts Avenue \\ Cambridge, MA 02138 \\ October 2005
}

I thank Joe Gagnon, Ufuk Demiroglu, Juann Hung, Catherine Mann, Jaime Marquez and Kei-Mu Yi for very helpful comments. The author acknowledges the hospitality of the Macroeconomic Analysis Division of the Congressional Budget Office, where part of this paper was written while he was visiting fellow. The views reported herein are solely those of the author's, and do not necessarily represent those of the institutions the author is currently or previously affiliated with. Faculty research funds of the University of Wisconsin-Madison are gratefully acknowledged. The views expressed herein are those of the author(s) and do not necessarily reflect the views of the National Bureau of Economic Research.

(C2005 by Menzie D. Chinn. All rights reserved. Short sections of text, not to exceed two paragraphs, may be quoted without explicit permission provided that full credit, including $\odot$ ) notice, is given to the source. 
Supply Capacity, Vertical Specialization and Tariff Rates: The Implications for Aggregate U.S. Trade Flow Equations

Menzie D. Chinn

NBER Working Paper No. 11719

October 2005

JEL No. F12, F41

\begin{abstract}
$\underline{\text { ABSTRACT }}$
This paper re-examines aggregate and disaggregate import and export demand functions for the United States. This re-examination is warranted because (1) income elasticities are too high to be warranted by standard theories, and (2) remain high even when it is assumed that supply factors are important. These findings suggest that the standard models omit important factors. An empirical investigation indicates that the rising importance of vertical specialization combined with decreasing tariffs rates explains some of results. Accounting for these factors yields more plausible estimates of income elasticities, as well as smaller prediction errors.

Menzie D. Chinn

Dept. of Economics

University of Wisconsin

1180 Observatory Drive

Madison, WI 53706

and NBER

mchinn@lafollette.wisc.edu
\end{abstract}




\section{Introduction}

This analysis is inspired by both current events - the widening of the trade deficit as a proportion of GDP, illustrated in Figure 1 - and recent findings of the persistence of the Houthakker-Magee results, namely that the income elasticity of U.S. imports exceeds that of exports. Over the past 30 years, the gap is at least 0.3 for total goods and services, regardless of the method of estimation. In Chinn (2005), the gap is as high as 0.65. Table 1 presents estimates obtained from OLS, dynamic OLS, single equation error correction estimates and the Johansen maximum likelihood procedures. Furthermore, there is little evidence that the asymmetry is disappearing. Breaking the last 30 years into three equal sub-periods, one obtains the income elasticities in Figure 2. In other words, the asymmetry is proving to be quite durable.

In addition, the absolute values of the income elasticities are quite high. In Table 1, the income elasticities are as high as 2.3 for imports, and 2.0 for exports. These large elasticities are difficult to reconcile with the standard differentiated goods model (see Goldstein and Khan, 1985). From a forecasting standpoint, high income elasticities ${ }^{1}$ are not troubling; but - as discussed below - from an economic perspective, they are perplexing. ${ }^{2}$ Finally, the behavior of trade flows during 1999-2000 is difficult to explain using standard models. As illustrated in Figure 3, both series surge in this period.

In this paper, I re-investigate the behavior of export and import flows, motivating the analysis by referring to new theories of trade behavior. These include differentiated goods models such as those forwarded by Krugman (1991). Such approaches yield some

\footnotetext{
1 This phenomenon has been noted before (Rose, 1991).

2 Barrell and Dées (2005) and Camerero and Tamarit (2003) address the issue of very high income elasticities by incorporating FDI.
} 
insights. In this paper, I adopt a different approach. Disaggregating the data, one finds that some of the odd behavior of goods exports and imports can be isolated to the peculiar behavior of capital goods; since such goods are often used to manufacture other capital goods or consumer goods, it seems that growth in such categories is blowing up the volume of such trade flows. Various papers have pointed out that the growth of such trade may be nonlinearly related to the decline in trade flows and the heightened importance of capital expenditures during certain phases of the business cycle. More recently, Mann (2005) has argued that disaggregation along category line and trading partner helps in obtaining reasonable parameter estimates.

Once one includes the variables that one thinks should matter for such vertical specialization, the parameter estimates become more plausible. That being said, the parameter estimates for the auxiliary variables are not always in the expected direction or statistically significant, and the results cannot be construed as definitive. In addition, the estimates based upon disaggregated data yield less biased estimates of the long run equilibrium levels of imports.

\section{The Standard Model and the Supply Side}

\subsection{The model specification}

The empirical specification is motivated by the traditional, partial equilibrium view of trade flows. Goldstein and Khan (1985) provide a clear exposition of this "imperfect substitutes" model. To set ideas consider the algebraic framework similar to that used by Rose (1991). Demand for imports in the US and the Rest-of-the-World (RoW) is given by: 


$$
\begin{aligned}
& D_{i m}^{U S}=f_{1}^{U S}\left(Y^{U S}, \hat{P}_{i m}^{U S}\right) \\
& D_{i m}^{R o W}=f_{1}^{R o W}\left(Y^{R o W}, \hat{P}_{i m}^{R o W}\right)
\end{aligned}
$$

where $\hat{P}_{i m}$ is the price of imports relative to the economy-wide price level. The supply of exports is given by:

$$
\begin{aligned}
& S_{e x}^{U S}=f_{2}^{U S}\left(\hat{P}_{e x}^{U S}, Z^{U S}\right) \\
& S_{e x}^{R o W}=f_{2}^{R o W}\left(\hat{P}_{e x}^{R o W}, Z^{R o W}\right)
\end{aligned}
$$

Where $\hat{P}_{e x}$ is the price of exports relative to the economy-wide price level. Note that the price of imports into the US is equal to the price of foreign exports adjusted by the real exchange rate.

$$
\hat{P}_{i m}^{U S} \times P^{U S}=E \times \hat{P}_{e x}^{R o W} \times P^{R o W} \Rightarrow \hat{P}_{i m}^{U S}=Q \hat{P}_{e x}^{R o W}
$$

where $E$ is the nominal exchange rate in US\$ per unit of foreign currency, the real exchange rate is

$$
Q=\frac{E P^{R o W}}{P^{U S}}
$$

where $P$ represents the aggregate level of prices of domestically produced goods and services. $Z$ is a supply shift variable, representing the productive capacity of the exportables sector.

An analogous equation applies for imports into the rest-of-the-world. Imposing the equilibrium conditions that supply equals demand, one can write out import and 
export equations (assuming log-linear functional forms, where lowercase letters denote $\log$ values of upper case) $:^{3}$

$$
\begin{aligned}
& i m_{t}=\beta_{0}+\beta_{1} q_{t}+\beta_{2} y_{t}^{U S}+\beta_{3} z^{R o W}+\varepsilon_{2 t} \\
& e x_{t}=\delta_{0}+\delta_{1} q_{t}+\delta_{2} y_{t}^{R o W}+\delta_{3} z^{U S}+\varepsilon_{1 t}
\end{aligned}
$$

Where $\beta_{1}<0, \beta_{2}>0, \beta_{3}>0$ and $\delta_{1}>0, \delta_{2}>0, \delta_{3}>0$.

Notice that exports are the residual of production over domestic consumption of exportables; similarly imports are the residual of foreign production over foreign consumption of tradables. The difference between this specification and the standard is the inclusion of the exportables supply shift variable, $z$. In standard import and export regressions, this term is omitted, implicitly holding the export supply curve fixed; in other words, it constrains the relationship between domestic consumption of exportables and production of exportables to be constant (see Helkie and Hooper, 1988 for an exception to this rule). A bout of consumption at home that reduces the supply available for exports would induce an apparent structural break in the equation (6) if the $z$ term is omitted. Similarly, omission of the rest-of-world export suppy term from the import equation makes the estimated relationships susceptible to structural breaks.

Note that the supply term here is explicitly partial equilibrium in nature. Unlike the Krugman (1991) model, where balanced trade implies supply creates its own demand, no specific presumptions are made regarding the source of this supply effect.

\footnotetext{
${ }^{3}$ As Marquez (1994) has pointed out, there are a number of problems with this specification, in terms of assumptions regarding expenditure shares. A number of other potentially important factors are also omitted, including other trend factors (e.g, immigration as in Marquez (2002) or the rise of services exports as in Mann (1999)).
} 
The problem, of course, is obtaining good proxies for these supply terms. Obvious candidates, such as US industrial production for US exports, exhibits too much collinearity with rest-of-world GDP) to identify the supply effect precisely. ${ }^{4}$ That is why this supply factor has typically been identified in panel cross section analyses (Bayoumi, 2003; Gagnon, 2004).

\subsection{Data and Estimation}

Data on real imports and exports of goods and services (2000 chain weighted dollars) were obtained for the 1967q1-2005q2 period (July 2005 release). Domestic economic activity was measured by U.S. GDP in 2000 chain weighted dollars. Foreign economic activity was measured by real Rest-of-World GDP, weighted by U.S. exports to major trading partners. The Federal Reserve Board's broad trade weighted value of the dollar is used. This index uses the CPI as the deflator. Additional details on all these variables are contained in Appendix 1.

Estimation is implemented on data spanning a period of 1975q1-2005q1 (I drop the preliminary estimate for GDP in 2005q2). This period spans three episodes of dollar appreciation and three episodes of dollar depreciation; the broad measure of dollar is used, as opposed to the major currencies measure, which as has been pointed out in recent reports, is unrepresentative of relative prices faced by the U.S. import competing sector in recent years (see Figure 4).

\footnotetext{
${ }^{4}$ In addition, industrial production is in some sense too "endogenous" a variable to include in the regression. An alternative is to obtain capital stock measures as a measure of the supply capacity of exportables, as in Helkie and Hooper (1988). The question is whether these variables are measured with too much error, especially to the extent that we want to capture the impact of the newly industrializing countries and China.
} 
The cointegrating relationship is identified using dynamic OLS (Stock and Watson, 1993). Two leads and four lags of the right hand side variables are included. In a simple two variable cointegrating relationship, the estimated regression equation is:

$$
y_{t}=\gamma_{0}+\gamma_{1} x_{t}+\sum_{i=+2}^{-4} \Gamma_{i} \Delta x_{t+i}+u_{t}
$$

Although this approach presupposes that there is only one long run relationship, this requirement is not problematic, as in these extended samples at least one cointegrating vector is usually detected.

\subsection{Empirical Results}

First we consider equations (6) and (7) suppressing the $z$ terms. The long run elasticities are reported in Table 2. The income elasticity for total exports of goods and services is 1.90 (Column [1]). This finding is not an artifact of the inclusion of services. In fact, the goods only elasticity is 1.96 (Column [3]). A similar result obtains for imports. As reported in Table 3, Column [1], total imports of goods and services exhibit a long run elasticity of 2.20 .

There is good reason to consider an import aggregate excluding petroleum. The trade equations in (6) and (7) are derived from an imperfect substitutes model, well suited to manufactured goods. However, oil is a natural resource commodity that does not quickly respond to market signals, and exhibits trends due to resource depletion.

Moreover, since Chinn (2005) findings of cointegration over the 1975q1-2001q2 period are sensitive to the inclusion of computers, I also consider an aggregate excluding these two commodity classes. ${ }^{5}$ In this case (Column [3]), the income elasticity is barely

\footnotetext{
${ }^{5}$ This procedure follows the lead of Lawrence (1990) and Meade (1991).
} 
altered: 2.22. Finally, a goods imports ex petroleum series (Column [5]) exhibits an even higher elasticity: 2.65 .

These results inform the debate over the durability of the Houthakker-Magee (1969) findings. Exports respond between 1.9 to 2.0 percent for each one percentage point increase in rest-of-world income. In contrast, imports rise about 2.2 to 2.7 percentage points for each percentage point increase in US GDP. This set of findings suggests that the Houthakker-Magee income asymmetry persists. Hence, even if U.S. and foreign growth rates were to converge, net exports would continue to deteriorate even starting from balanced trade. Obviously, starting from an initial trade deficit, the deterioration would be even more rapid.

All of the preceding specifications exclude a role for the supply side, suggested by Equations (6) and (7). As noted earlier, it is hard to find good measures of the supply side. Helkie and Hooper (1988) used a measure of relative capital stocks; but it is hard to think of how one would accurately estimate the relevant rest of the world capital stock, especially with the entry of China.

For exports, accounting for supply is fairly successful. In Table 2, when U.S. industrial production is included, the export income elasticity falls from 2.0 to 1.1 , with the supply coefficient equal to close to unity (Column [7]). Unfortunately, this point estimate is sensitive to the inclusion of a time trend (Column [8]). If one proxies the supply of exports with U.S. GDP (and constrains the coefficients on supply and demand to be equal), then one once again obtains a significant effect, close to unity, regardless of whether a time trend is included or not (Columns [9] and [10]). 
On the import side, the inclusion of supply side effects is less successful. In Table 3, Column [9], the import income elasticity rises to 2.92 from 2.60 , with the coefficient on industrial country industrial production equal to negative 0.40 . This perverse finding suggests that industrial country industrial production is not the correct proxy measure. A better measure would probably incorporate LDC industrial production. Constraining the coefficients on U.S. GDP and rest-of-world GDP to be equal yields more sensible coefficients (Columns [11] and [12]). Unfortunately, in all these instances, the demand and supply variables are so collinear that one can't be certain of stability of the results. ${ }^{6}$ This is why cross-section and panel regressions such as Gagnon (2003) and Bayoumi (2003) obtain more supportive evidence of supply side effects.

\section{Vertical Specialization and Tariffs}

One hint of why the income elasticities are so large is provided by the surge in both exports and imports during 1999-2000. In informal discussions, this jump is associated with the investment boom; the category experiencing the largest jump is capital goods.

The fact that the surge and collapse occurred in both categories could be coincidence - evidence of a worldwide investment boom. Or it could be a reflection that the two are interlinked.

Recent research has focused on the rise of intermediate goods in international trade. However, intermediate goods are not in and of themselves sufficient to explain the rise in trade. It is intermediate goods trade used to produce other traded goods - in other words vertical specialization (Hummels, et al., 2001; Yi, 2003; Chen et al., 2005). This

\footnotetext{
${ }^{6}$ The slope coefficient of a regression of U.S. GDP on rest-of-world GDP is 0.93 , with
} 
process of importing in order to export has also been termed "fragmentation" of production (Arndt, 1997). At this juncture, it is useful to recognize that services exhibit less of this fragmentation. This explains in part the differential import income elasticities: 2.65 for goods ex oil versus 1.70 for services. ${ }^{7}$

Table 4 estimates the basic regressions specification (trade flow on income and real exchange rate) for the trade flow ex capital goods and capital goods trade flows. For the specifications excluding a time trend, goods exports ex capital goods (Column [1]) exhibit an income elasticity of 1.35 while capital goods exports (Column [3]) exhibit an elasticity of 2.96. For imports, this pattern is repeated, but more sharply. The income elasticity for total goods imports ex oil and capital goods is 1.87 , while that for capital goods is nearly 4.82, for specifications excluding time trends (Columns [5] and [7]). In both cases, the trend-augmented specifications exhibit a similar, although less pronounced, pattern.

These findings suggest two not necessarily inconsistent conclusions. First, that it is important to disaggregate goods exports and imports in order to model aggregate trade flows. Second, if one is to model aggregate goods flows, one needs to include the measures that have a specific impact on the capital goods portions.

Figures 5 and 6 show how goods and goods excluding capital goods for exports and imports respectively behave. Note that the series excluding capital goods exhibits much less of a pronounced hump. Figure 7 illustrates how capital goods exports and imports covary with investment in equipment and software, particularly in the 1999-2001

adjusted $\mathrm{R}^{2}$ over 0.99 .

${ }^{7}$ Marquez (2005) obtains similar estimates, but points out that further disaggregation of services leads to different insights on income and price elasticities. 
period. The importance of vertical specialization was suggested, particularly for hi-tech goods, in analyses around the time of the capital goods surges (e.g., Council of Economic Advisers, 2001, Chapter 4).

The regression results in Column [1] of Table 5 indicate the impact of U.S. investment in equipment and software on total goods exports: income now has unit elastic impact, while investment has an elasticity of 0.57. Yi (2003) argues that reductions in the tariff rate have induced large, non-proportionate, changes in the extent of vertical specialization. To incorporate this factor, we augment the regression with the (square of the) average tariff rate of the US, Europe and Japan. This variable does not enter with the correct sign or statistical significance for total goods exports, while leaving the other coefficients relatively unchanged (Column [2]).

Interestingly, for goods exports ex capital goods (Column [3]), the tariff rate has an incorrect and statistically significant coefficient estimate, while investment has a much lower coefficient (although still statistically significant). When examining capital goods exports (Column [4]), the income elasticity is about unity and the price elasticity is very high, at 1.6. Investment also enters in with unit elasticity, while squared tariff rate enters with a statistically significant and negative coefficient. Hence, for capital goods, the vertical specialization hypothesis is not contradicted.

Examining non-oil goods imports in a specification augmented in by investment (Column [5]) yields a relatively high income elasticity of 2.34 (although lower than 2.65). Investment is statistically significant, as expected. Augmenting the specification with the tariff rate squared (Column [6]) yields a statistically significant coefficient on this variable, in the expected direction, while raising the investment coefficient. This is 
suggestive that the decline in tariff rates and the rise in investment are correlated. In addition the income coefficient declines to 1.5 ; most likely income was picking up the trend in the tariff variable in the standard specifications. Non-oil, non-capital goods imports (Column [7]) show a minor effect from investment and statistically insignificant effect from tariffs.

In contrast, imports of capital goods (Columns [8]) exhibit an implausibly strong responsiveness to income and tariff rates (although exchange rates exhibit wrong signedness and equipment and software expenditures are not statistically significant).

The fact that capital imports drop precipitously after 2000, while GDP only plateaus, suggests dropping the income variable (Column [9]). This idea is also motivated by Mann and Plück's (forthcoming) finding that matched expenditure classes sometime work better than aggregate income as an activity variable. This still yields an incorrect sign on the exchange rate. Only when augmenting the specification with a time trend and an interaction of time with the exchange rate does one obtain a positive coefficient on the exchange rate (early in the sample). Toward the end of the sample, the exchange rate coefficient becomes negative.

\section{Long Run Equilibria and Actual Values}

One potential benefit of obtaining a better fit for the trade flows, aside from a greater understanding of the economic mechanisms at work, is that better predictions might be possible. What has proven particularly challenging is adequately modeling imports; hence in this section I investigate whether one can improve upon the predictions obtained using only aggregate data. In Figure 9, the long run equilibrium values from the 
a simple DOLS incorporating only income and exchange rates (conforming to Column [5] of Table 3) is depicted, alongside the actual log level of real non-petroleum imports (the actual dynamic OLS fit, incorporating the short run dynamics, matches almost exactly the actual). In Figure 10, the actual and long run equilibria for log non-oil noncapital goods imports and capital goods imports are depicted (conforming to Columns [8] and [9] respectively of Table 5). Once again, short run dynamics are omitted from the predictions.

In principle it would be useful to compare the prediction errors obtained from the equation estimated using the aggregate non-oil imports, and compare it against the summed prediction errors for the components, non-oil non-capital goods imports and capital goods imports. However, because the trade flows are "chained" quantities that do not obey adding up constraints, this procedure is not appropriate.

Instead, I convert the predicted long run flows into nominal flows using the ex post price indices. These actual and nominal trade flows can then be added and subtracted. Then, to make the errors somehow comparable over time, I normalize by GDP. The prediction error for the aggregate specification is compared against the sum of the prediction errors for the components in Figure 11. On average, using the disaggregated data yields smaller mean error: 0.1085 percentage points (ppts) of GDP versus 0.3754 ppts. In addition, the standard deviation of the errors is slightly smaller: 0.3196 ppts. versus 0.3602 ppts. In addition, the disaggregate procedure does better in the boom of the 1990's, including the investment boom of 2000-01.

Of course, not all problems are solved. Both approaches underpredict the recent level of non-oil imports, by about 0.37 ppts. of GDP in 2004. 


\section{Summary}

In this paper the data for U.S. trade flows up to the beginning of 2005 are investigated. The results indicate:

- The Houthakker-Magee finding persists for the standard aggregates.

- The income elasticities for imports and exports are quite high in regressions involving only GDP and exchange rates.

- The inclusion of supply-side variables reduces the magnitude of the income elasticities for exports. However, the results are not robust.

- Capital goods and non-capital goods imports appear to behave differently. Capital goods exports respond strongly to investment in equipment and software, and tariff rates.

- Capital goods imports are difficult to model.

- Prediction using disaggregated imports yields smaller errors than prediction using aggregate imports. 


\section{References}

Barrell, Ray and Stephane Dées, 2005, "World Trade and Global Integration in Production Processes: A Re-assessment of Import Demand Equations," ECB Working Paper No. 503 (Frankfurt: European Central Bank, July).

Bayoumi, Tamim, 2003, "Estimating Trade Equations from Aggregate Bilateral Data," mimeo (Washington, D.C.: IMF, December).

Bayoumi, Tamim, Jaewoo Lee, and Sarma Jayantha, 2005, "New Rates from New Weights,” Working Paper No. WP/05/99 (Washington, DC: IMF, May).

Camarero, Mariam and Cecilio Tamarit, 2003, "Estimating the export and import demand for manufactured goods: The role of FDI," Leverhulme Center Research Paper Series No. 2003/34 (Nottingham: University of Nottingham).

Chen, Hogan, Matthew Kondratowicz and Kei-Mu Yi, 2005, "Vertical Specialization and Three Facts about U.S. International Trade," North American Journal of Economics and Finance 16: 35-59

Chinn, Menzie D., 2005, "Doomed to Deficits? Aggregate U.S. Trade Flows Reexamined," Review of World Economics 141(3): 460-85. Revision of NBER Working Paper No. 9521 (February 2003).

Council of Economic Advisers, 2001, Economic Report of the President, 2001 (Washington, D.C.: U.S. GPO, January).

Gagnon, Joseph E., 2003, "Productive Capacity, Product Varieties, and the Elasticities Approach to the Trade Balance," International Finance and Discussion Papers No. 781 (October).

Goldstein, Morris, and Mohsin Khan, 1985, Income and Price Effects in Foreign Trade, in R. Jones and P. Kenen (eds.), Handbook of International Economics, Vol. 2, (Amsterdam: Elsevier).

Helkie, William and Peter Hooper, 1988, “The U.S. External Deficit in the 1980's: An Empirical Analysis," in R. Bryant, G. Holtham and P. Hooper (eds.) External Deficits and the Dollar: The Pit and the Pendulum. Washington, DC: Brookings Institution.

Hooper, Peter, Karen Johnson and Jaime Marquez, 2000, Princeton Studies in International Economics No. 87 (Princeton, NJ: Princeton University).

Houthakker, Hendrik, and Stephen Magee, 1969, Income and Price Elasticities in World Trade, Review of Economics and Statistics 51: 111-25. 
Hummels, David, Jun Ishii, and Kei-Mu Yi, 2001, “The Nature and Growth of Vertical Specialization in World Trade," Journal of International Economics 54: 75-96.

Johansen, Søren, 1988, Statistical Analysis of Cointegrating Vectors. Journal of Economic Dynamics and Control 12: 231-54.

Johansen, Søren, and Katerina Juselius, 1990, Maximum Likelihood Estimation and Inference on Cointegration - With Applications to the Demand for Money. Oxford Bulletin of Economics and Statistics 52: 169-210.

Lawrence, Robert Z., 1990, "U.S. Current Account Adjustment: An Appraisal," Brookings Papers on Economic Activity No. 2: 343-382.

Leahy, Michael P., 1998, New Summary Measures of the Foreign Exchange Value of the Dollar. Federal Reserve Bulletin (October): 811-818.

Loretan, Mico, 2005, "Indexes of the Foreign Exchange Value of the Dollar," Federal Reserve Bulletin (Winter): 1-8.

Mann, Catherine, 1999, Is the U.S. Trade Deficit Sustainable (Washington, DC: Institute for International Economics).

Mann, Catherine, and Katharina Plück, forthcoming, "The U.S. Trade Deficit: A Disaggregated Perspective," in Richard Clarida (ed.), G7 Current Account Imbalances: Sustainability and Adjustment (U.Chicago Press).

Marquez, Jaime, 2005, "Estimating Elasticities for U.S. Trade in Services," International Finance Discussion Papers No. 836. Washington, D.C.: Board of Governors of the Federal Reserve System, August.

Marquez, Jaime, 2002, Estimating Trade Elasticities, Advanced Studies in Theoretical and Applied Econometrics, Vol. 39. Boston; Dordrecht and London: Kluwer Academic.

Marquez, Jaime, 1994, "The Econometrics of Elasticities or the Elasticity of Econometrics: An Empirical Analysis of the Behavior of U.S. Imports," Review of Economics and Statistics 76(3) (August): 471-481.

Meade, Ellen, 1991, "Computers and the Trade Deficit: the case of the falling prices," in Peter Hooper and David Richardson, (eds.) International Economic Transactions: Issues in Measurement and Empirical Research, NBER Studies in Income and Wealth vol. 55.

Stock, James H. and Mark W. Watson, 1993, “A Simple Estimator of Cointegrating Vectors in Higher Order Integrated Systems," Econometrica 61(4): 783-820. 
Whelan, Karl, 2000, "A Guide to the Use of Chain Aggregated NIPA Data," Finance and Economics Discussion Papers No. 2000-35. Washington, DC: Board of Governors of the Federal Reserve System.

Yi, Kei-Mu, 2003, "Can Vertical Specialization Explain the Growth of World Trade?" Journal of Political Economy 111(1): 53-102. 
Table 1: Differing Estimates of Export and Import Elasticities

\begin{tabular}{|c|c|c|c|c|c|c|c|c|}
\hline & \multicolumn{4}{|c|}{$\begin{array}{l}\text { Exports of Goods and } \\
\text { Services }\end{array}$} & \multicolumn{4}{|c|}{$\begin{array}{l}\text { Imports of Goods and } \\
\text { Services }\end{array}$} \\
\hline & OLS & DOLS $^{\mathrm{a} /}$ & ECM & VECM & OLS & DOLS$^{\underline{a} /}$ & $\mathrm{ECM}^{\mathrm{b} /}$ & VECM \\
\hline & [1] & [2] & [3] & [4] & [5] & [6] & [7] & [8] \\
\hline Income & 1.875 & 1.896 & 1.915 & 1.993 & 2.203 & 2.196 & 2.246 & 2.282 \\
\hline (Demand) & {$[0.021]$} & {$[0.017]$} & {$[0.054]$} & {$[0.068]$} & {$[0.020]$} & {$[0.019]$} & & {$[0.069]$} \\
\hline Exchange rate & $\begin{array}{c}0.491 \\
{[0.062]}\end{array}$ & $\begin{array}{c}0.612 \\
{[0.056]}\end{array}$ & $\begin{array}{c}0.914 \\
{[0.191]}\end{array}$ & $\begin{array}{c}0.828 \\
{[0.216]}\end{array}$ & $\begin{array}{l}-0.200 \\
{[0.0551}\end{array}$ & $\begin{array}{l}-0.202 \\
{[0.0611}\end{array}$ & -0.281 & -0.169 \\
\hline Adj. R2 & 0.99 & 0.99 & 0.37 & na & 0.99 & 0.99 & 0.34 & na \\
\hline SER & 0.065 & 0.050 & 0.018 & na & 0.058 & 0.054 & 0.024 & na \\
\hline $\mathrm{N}$ & 121 & 119 & 121 & 121 & 121 & 119 & 121 & 121 \\
\hline Coint. Vectors & na & na & 1 & 1,1 & na & na & 1 & 1,1 \\
\hline
\end{tabular}

Notes: Point estimates and HAC standard errors for OLS and DOLS in [brackets], implied long run coefficients from ECM and cointegrating vector coefficients for VECM [asymptotic standard errors in brackets]. SER is standard error of estimates. $\mathrm{N}$ is number of observations.

Cointegrating vectors is the number of indicated cointegrating vectors; under VECM, $\{\#, \#\}$ indicates the number of vectors as indicated by the trace and maximal eigenvalue statistics at the $5 \%$ level, using the asymptotic critical values. [bold face] indicates significance at the $10 \%$ level. a/ Includes 2 leads and 4 lags of the first difference terms of the right hand side variables.

b/ Implied long run coefficients from unconstrained ECM. 


\section{Table 2: Export Equations}

\begin{tabular}{|c|c|c|c|c|c|c|c|c|c|c|}
\hline & $\begin{array}{l}\text { Total } \\
\text { goods \& } \\
\text { svcs. }\end{array}$ & $\begin{array}{l}\text { Total } \\
\text { goods \& } \\
\text { svcs. }\end{array}$ & $\begin{array}{l}\text { Total } \\
\text { goods }\end{array}$ & $\begin{array}{l}\text { Total } \\
\text { goods }\end{array}$ & $\begin{array}{l}\text { Total } \\
\text { svcs. }\end{array}$ & $\begin{array}{l}\text { Total } \\
\text { svcs. }\end{array}$ & $\begin{array}{l}\text { Total } \\
\text { goods, } \\
\text { supply } \\
\text { side }\end{array}$ & $\begin{array}{l}\text { Total } \\
\text { goods, } \\
\text { supply } \\
\text { side }\end{array}$ & $\begin{array}{l}\text { Total } \\
\text { goods, } \\
\text { supply } \\
\text { side }\end{array}$ & $\begin{array}{l}\text { Total } \\
\text { goods, } \\
\text { supply } \\
\text { side }\end{array}$ \\
\hline & [1] & [2] & [3] & [4] & [5] & [6] & [7] & [8] & [9] & [10] \\
\hline Income & 1.896 & 2.234 & 1.961 & 2.551 & 1.749 & 1.044 & 1.071 & -0.569 & 1.026 & 1.364 \\
\hline (Demand) & [0.039] & [1.122] & {$[0.048]$} & [1.401] & {$[0.034]$} & [1.143] & {$[0.162]$} & [1.180] & [0.019] & {$[0.511]$} \\
\hline Output & & & & & & & 1.098 & 1.191 & 1.026 & 1.364 \\
\hline (Supply) & & & & & & & {$[0.189]$} & {$[0.202]$} & {$[0.019]$} & {$[0.511]$} \\
\hline Exchange Rate & 0.612 & 0.581 & $\begin{array}{c}0.640 \\
0.1231\end{array}$ & 0.587 & $\begin{array}{c}0.509 \\
0\end{array}$ & $\begin{array}{r}0.572 \\
01031\end{array}$ & $\begin{array}{c}0.741 \\
0\end{array}$ & 0.898 & 0.657 & 0.641 \\
\hline time & & $\begin{array}{l}-0.003 \\
{[0.009]}\end{array}$ & & $\begin{array}{l}-0.005 \\
{[0.011]}\end{array}$ & & $\begin{array}{c}{[0.100]} \\
0.006 \\
{[0.010]}\end{array}$ & & $\begin{array}{c}{[0.1<0]} \\
0.013 \\
{[0.009]}\end{array}$ & & $\begin{array}{l}{[0.005} \\
{[0.008]}\end{array}$ \\
\hline Adj. R2 & 0.99 & 0.99 & 0.99 & 0.99 & 0.99 & 0.99 & 0.99 & 0.99 & 0.99 & 0.99 \\
\hline SER & 0.050 & 0.050 & 0.063 & 0.063 & 0.050 & 0.050 & 0.043 & 0.042 & 0.059 & 0.059 \\
\hline $\mathrm{N}$ & 119 & 119 & 119 & 119 & 119 & 119 & 119 & 119 & 119 & 119 \\
\hline
\end{tabular}

Notes: Point estimates and HAC standard errors for OLS and DOLS in [brackets]. SER is standard error of estimates. $\mathrm{N}$ is number of observations. Regressions include 2 leads and 4 lags of the first difference terms of the right hand side variables. [bold face] indicates significance at the $10 \%$ level. 
Table 3: Import Equations

\begin{tabular}{|c|c|c|c|c|c|c|c|c|c|c|c|c|}
\hline & $\begin{array}{l}\text { Total } \\
\text { goods \& } \\
\text { svcs. }\end{array}$ & $\begin{array}{l}\text { Total } \\
\text { goods \& } \\
\text { svcs. }\end{array}$ & $\begin{array}{l}\text { Total } \\
\text { goods \& } \\
\text { svcs. } \\
\text { Ex oil, } \\
\text { comp. }\end{array}$ & $\begin{array}{l}\text { Total } \\
\text { goods \& } \\
\text { svcs. } \\
\text { Ex oil, } \\
\text { comp. }\end{array}$ & $\begin{array}{l}\text { Total } \\
\text { goods } \\
\text { ex oil }\end{array}$ & $\begin{array}{l}\text { Total } \\
\text { goods } \\
\text { ex oil }\end{array}$ & $\begin{array}{l}\text { Total } \\
\text { svcs. }\end{array}$ & $\begin{array}{l}\text { Total } \\
\text { sves. }\end{array}$ & $\begin{array}{l}\text { Total } \\
\text { goods } \\
\text { ex oil, } \\
\text { supply } \\
\text { side }\end{array}$ & $\begin{array}{l}\text { Total } \\
\text { goods } \\
\text { ex oil, } \\
\text { supply } \\
\text { side }\end{array}$ & $\begin{array}{l}\text { Total } \\
\text { goods } \\
\text { ex oil, } \\
\text { supply } \\
\text { side }\end{array}$ & $\begin{array}{l}\text { Total } \\
\text { goods } \\
\text { ex oil, } \\
\text { supply } \\
\text { side }\end{array}$ \\
\hline & [1] & [2] & [3] & [4] & [5] & [6] & [7] & [8] & [9] & [10] & [11] & [12] \\
\hline Income & 2.196 & 3.079 & 2.222 & 2.044 & 2.647 & 2.268 & 1.701 & 2.034 & 2.921 & 2.600 & 1.273 & 1.287 \\
\hline (Demand) & {$[0.041]$} & [0.548] & {$[0.017]$} & {$[0.246]$} & {$[0.019]$} & [0.382] & {$[0.028]$} & [0.496] & [0.336] & [0.567] & {$[0.010]$} & {$[0.278]$} \\
\hline Output & & & & & & & & & -0.404 & -0.286 & 1.273 & 1.287 \\
\hline (Supply) & & & & & & & & & [0.480] & [0.490] & {$[0.010]$} & {$[0.278]$} \\
\hline Exchange Rate & -0.202 & -0.220 & -0.497 & -0.493 & -0.463 & -0.455 & -0.340 & -0.346 & -0.436 & -0.444 & -0.605 & -0.606 \\
\hline & {$[0.109]$} & [0.095] & {$[0.047]$} & {$[0.046]$} & {$[0.067]$} & {$[0.067]$} & [0.098] & [0.095] & {$[0.077]$} & {$[0.074]$} & [0.073] & {$[0.075]$} \\
\hline time & & $\begin{array}{c}-0.007 \\
{[0.004]}\end{array}$ & & $\begin{array}{c}0.001 \\
{[0.002]}\end{array}$ & & $\begin{array}{c}0.003 \\
{[0.003]}\end{array}$ & & $\begin{array}{c}-0.003 \\
{[0.004]}\end{array}$ & & $\begin{array}{c}0.002 \\
{[0.003]}\end{array}$ & & $\begin{array}{c}0.000 \\
{[0.005]}\end{array}$ \\
\hline Adj. R2 & 0.99 & 0.99 & 0.99 & 0.99 & 0.99 & 0.99 & 0.05 & 0.99 & 0.99 & 0.99 & 0.99 & 0.99 \\
\hline SER & 0.054 & 0.053 & 0.028 & 0.028 & 0.035 & 0.035 & 0.052 & 0.052 & 0.034 & 0.035 & 0.036 & 0.036 \\
\hline $\mathrm{N}$ & 120 & 120 & 120 & 120 & 120 & 120 & 120 & 120 & 120 & 120 & 120 & 120 \\
\hline
\end{tabular}

Notes: Point estimates and HAC standard errors for OLS and DOLS in [brackets]. SER is standard error of estimates. $\mathrm{N}$ is number of observations. Regressions include 2 leads and 4 lags of the first difference terms of the right hand side variables. [bold face] indicates significance at the $10 \%$ level. 
Table 4: Capital Goods versus Non-Capital Goods Trade Flows

\begin{tabular}{|c|c|c|c|c|c|c|c|c|}
\hline & Exports & & & & Imports & & & \\
\hline & $\begin{array}{l}\text { Total } \\
\text { goods } \\
\text { ex } \\
\text { capital } \\
\text { goods }\end{array}$ & $\begin{array}{l}\text { Total } \\
\text { goods } \\
\text { ex } \\
\text { capital } \\
\text { goods }\end{array}$ & $\begin{array}{l}\text { Capital } \\
\text { goods }\end{array}$ & $\begin{array}{l}\text { Capital } \\
\text { goods }\end{array}$ & $\begin{array}{l}\text { Total } \\
\text { goods } \\
\text { ex oil, } \\
\text { capital } \\
\text { goods }\end{array}$ & $\begin{array}{l}\text { Total } \\
\text { goods } \\
\text { ex oil, } \\
\text { capital } \\
\text { goods }\end{array}$ & $\begin{array}{l}\text { Capital } \\
\text { goods }\end{array}$ & $\begin{array}{l}\text { Capital } \\
\text { goods }\end{array}$ \\
\hline & [1] & [2] & [3] & [4] & [5] & [6] & [7] & [8] \\
\hline Income & 1.350 & 2.308 & 2.956 & 2.940 & 1.948 & 1.870 & 4.816 & 2.054 \\
\hline (Demand) & {$[0.020]$} & [0.594] & {$[0.092]$} & [2.641] & {$[0.014]$} & {$[0.258]$} & [0.125] & [1.279] \\
\hline Exchange Rate & 0.406 & 0.420 & 0.898 & 0.900 & -0.589 & -0.587 & -0.216 & -0.161 \\
\hline & {$[0.053]$} & {$[0.062]$} & {$[0.218]$} & {$[0.319]$} & {$[0.045]$} & {$[0.045]$} & [0.364] & {$[0.317]$} \\
\hline time & & -0.008 & & 0.000 & & 0.001 & & 0.021 \\
\hline & & {$[0.005]$} & & [0.022] & & [0.002] & & {$[0.010]$} \\
\hline Adj. R2 & 0.99 & 0.99 & 0.98 & 0.98 & 0.99 & 0.99 & 0.99 & 0.99 \\
\hline SER & 0.033 & 0.032 & 0.114 & 0.114 & 0.028 & 0.028 & 0.152 & 0.146 \\
\hline $\mathrm{N}$ & 119 & 119 & 119 & 119 & 119 & 119 & 119 & 119 \\
\hline
\end{tabular}

Notes: Point estimates and HAC standard errors for OLS and DOLS in [brackets]. SER is standard error of estimates. $\mathrm{N}$ is number of observations. Regressions include 2 leads and 4 lags of the first difference terms of the right hand side variables. [bold face] indicates significance at the $10 \%$ level. 
Table 5: Vertical Specialization and Trade Flows

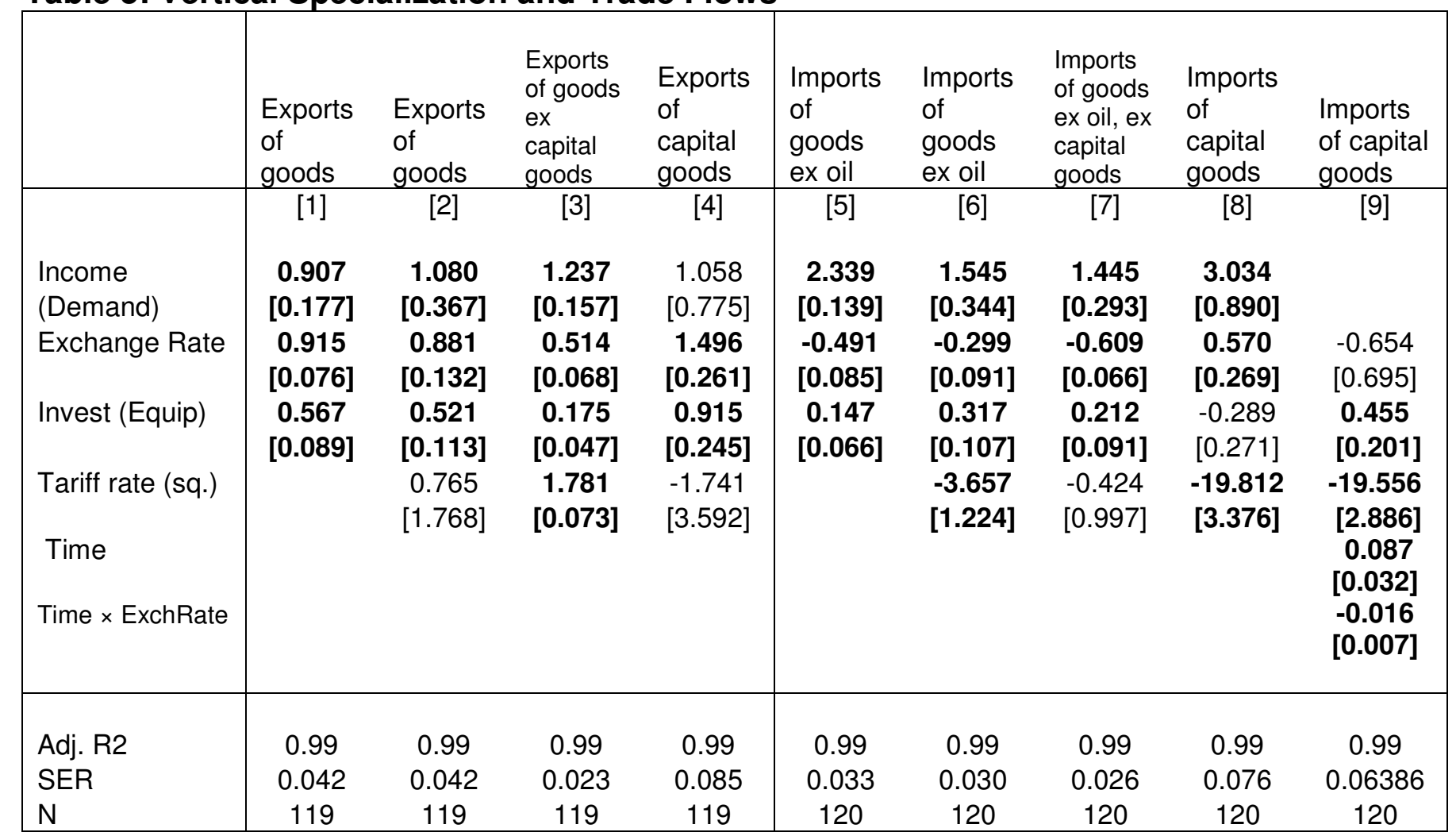

Notes: Point estimates and HAC standard errors for OLS and DOLS in [brackets].. SER is standard error of estimates. N is number of observations. Regressions include 2 leads and 4 lags of the first difference terms of the right hand side variables. [bold face] indicates significance at the $10 \%$ level. 


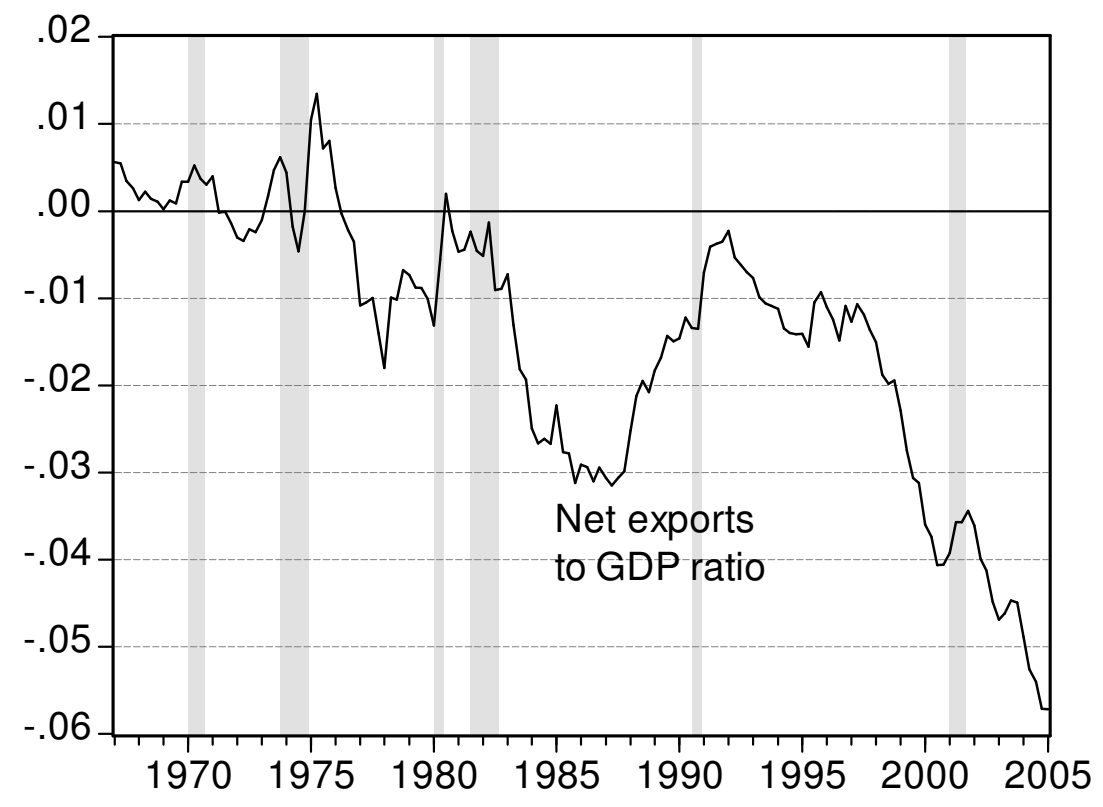

Figure 1: Net Exports of goods and services to GDP ratio, SAAR. Shaded areas denote recession dates. Source: BEA (July 2005) and NBER for recession dates.

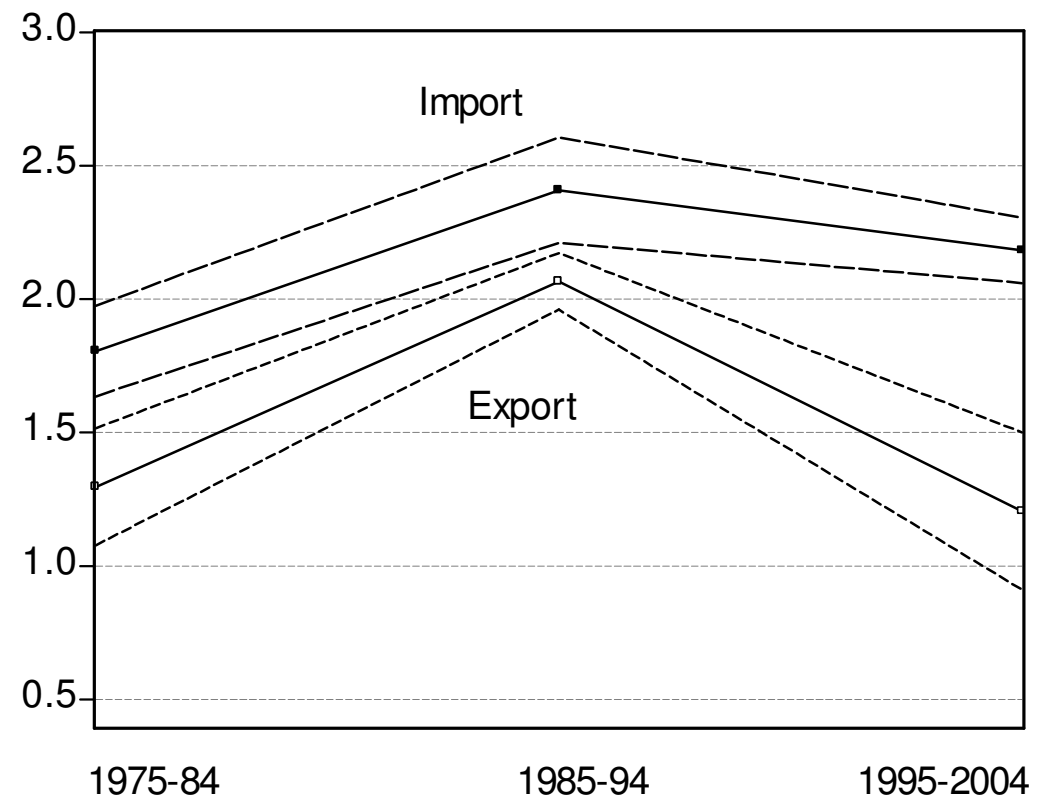

Figure 2: Income Export and Import Elasticities for Subperiods ( \pm 2 standard error bands). Source: Author's calculations based upon DOLS regressions. 


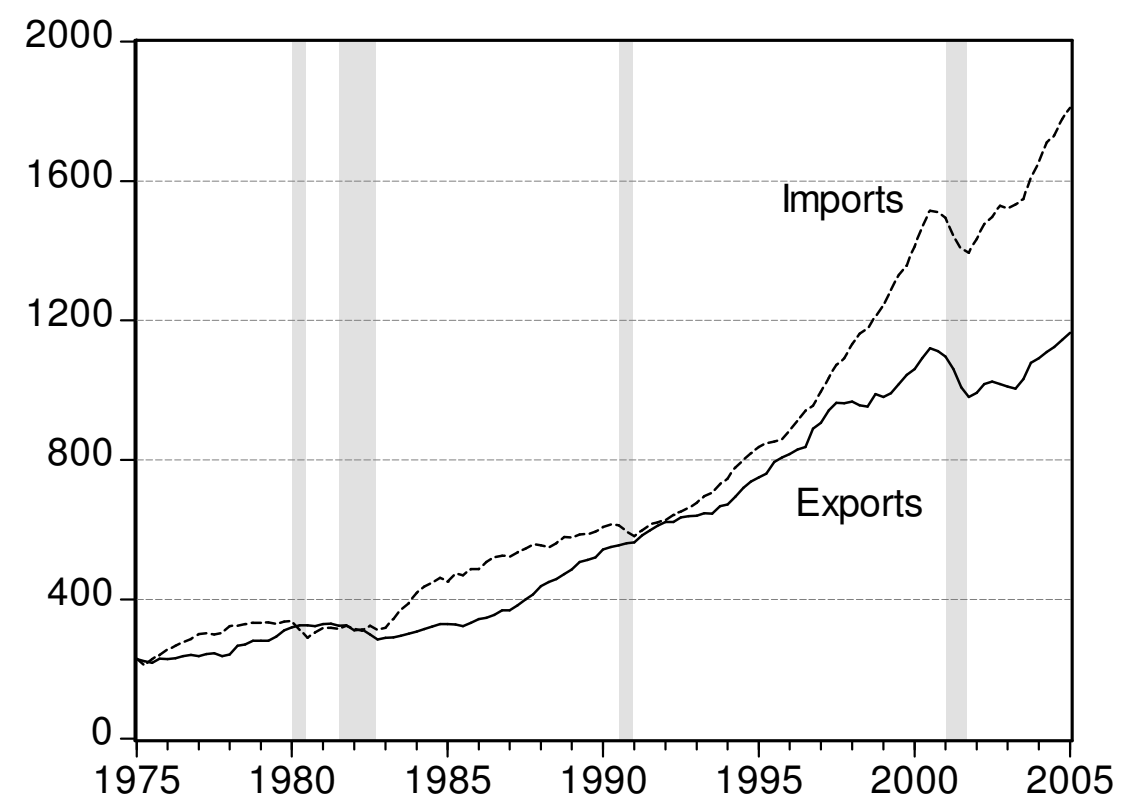

Figure 3: Real Exports and Imports of Goods and Services, in $2000 \mathrm{Ch} \$$ (SAAR). Source: BEA (July 2005).

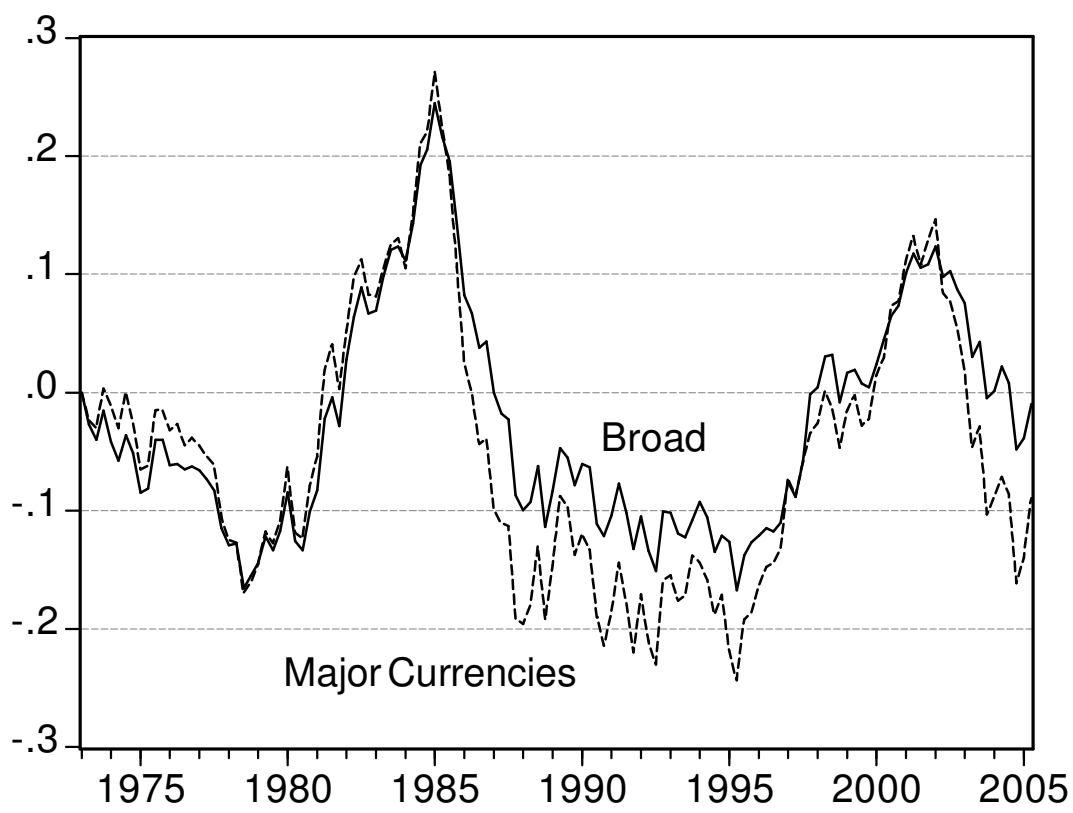

Figure 4: Federal Reserve Board Broad and Major Currencies Indices of the Real Value of the Dollar, in logs, 1973q1=0. Source: Federal Reserve Board. 


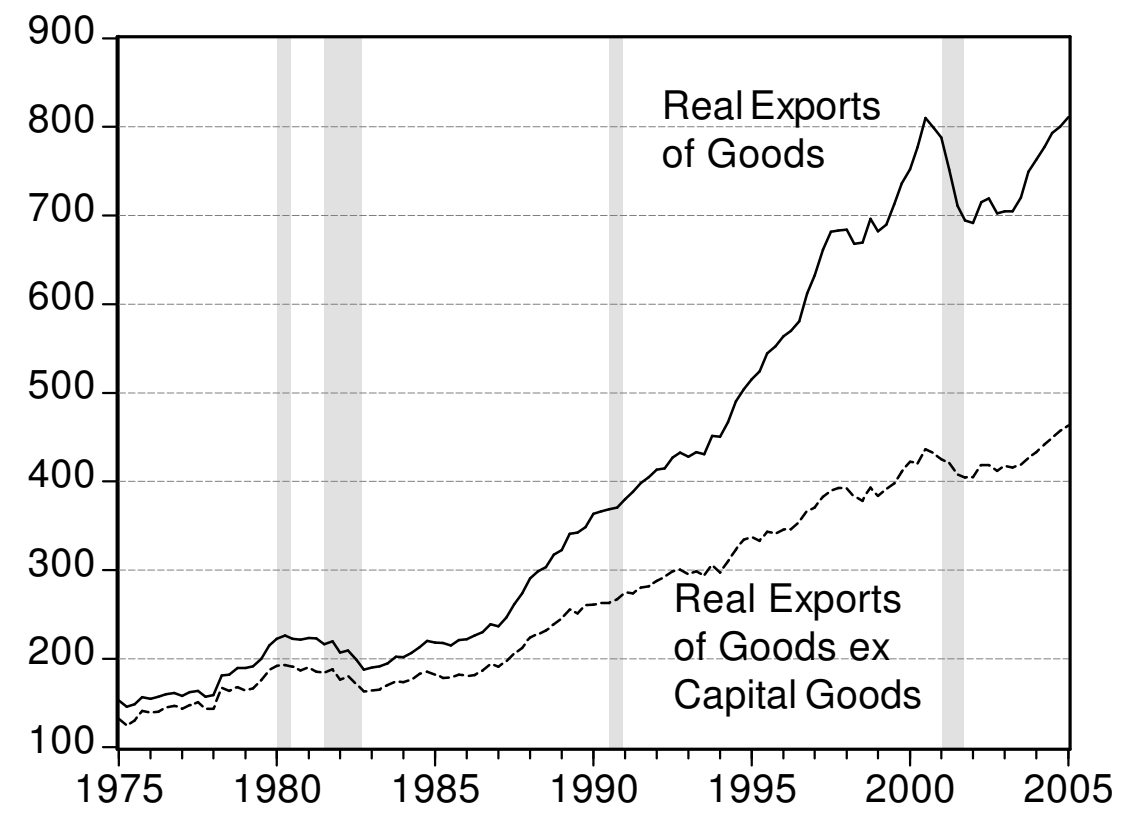

Figure 5: Real Exports of Goods and Goods ex Capital Goods, billions of 2000 Ch.\$, SAAR. Source: BEA (July 2005), and author's calculations.

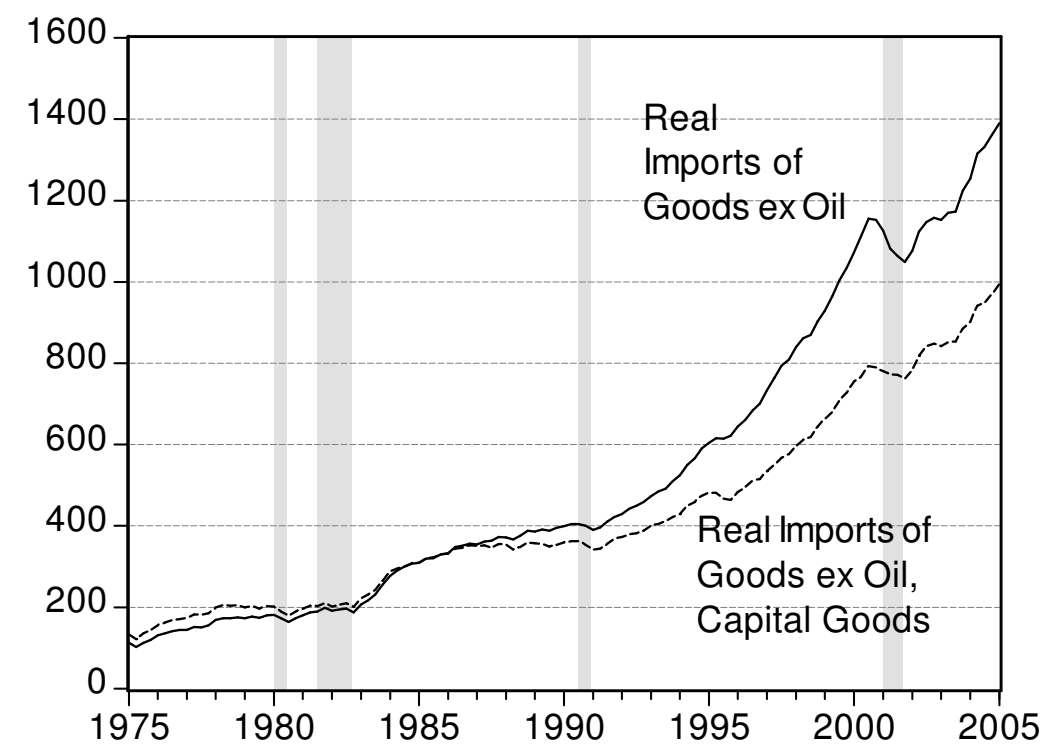

Figure 6: Real Imports of Goods ex Oil and Goods ex Oil, Capital Goods, billions of 2000 Ch.\$, SAAR. Source: BEA (July 2005), and author's calculations. 


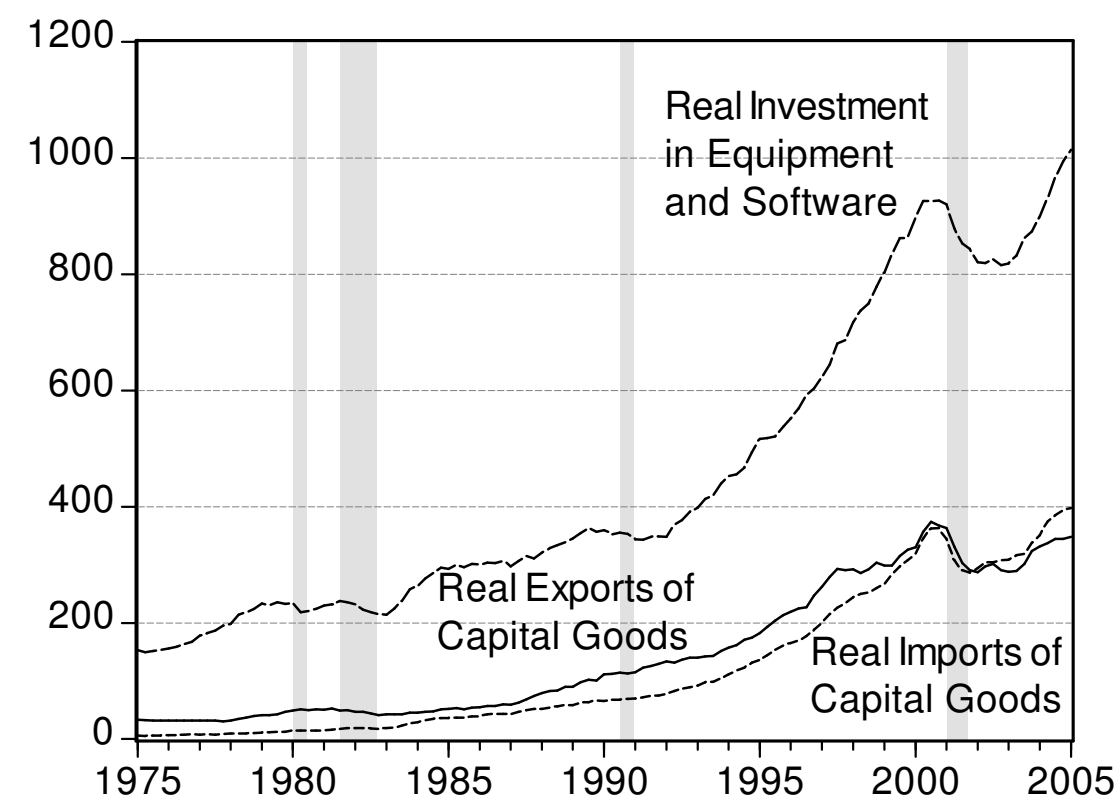

Figure 7: Real Exports and Imports of Capital Goods and Investment in Equipment and Software, billions of 2000 Ch.\$, SAAR. Source: BEA (July 2005).

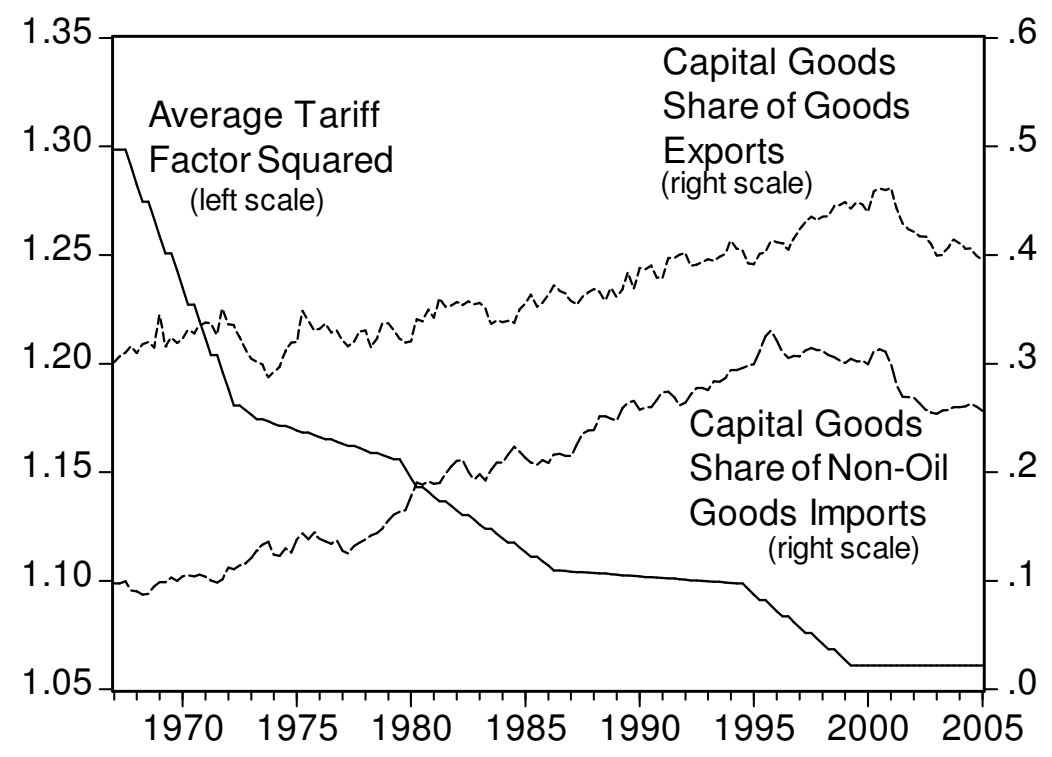

Figure 8: Average Tariff Factor Squared and Share of Capital Goods in Goods Exports and Goods Imports ex Oil. Source: Kei-Mu Yi, BEA and author's calculations. 


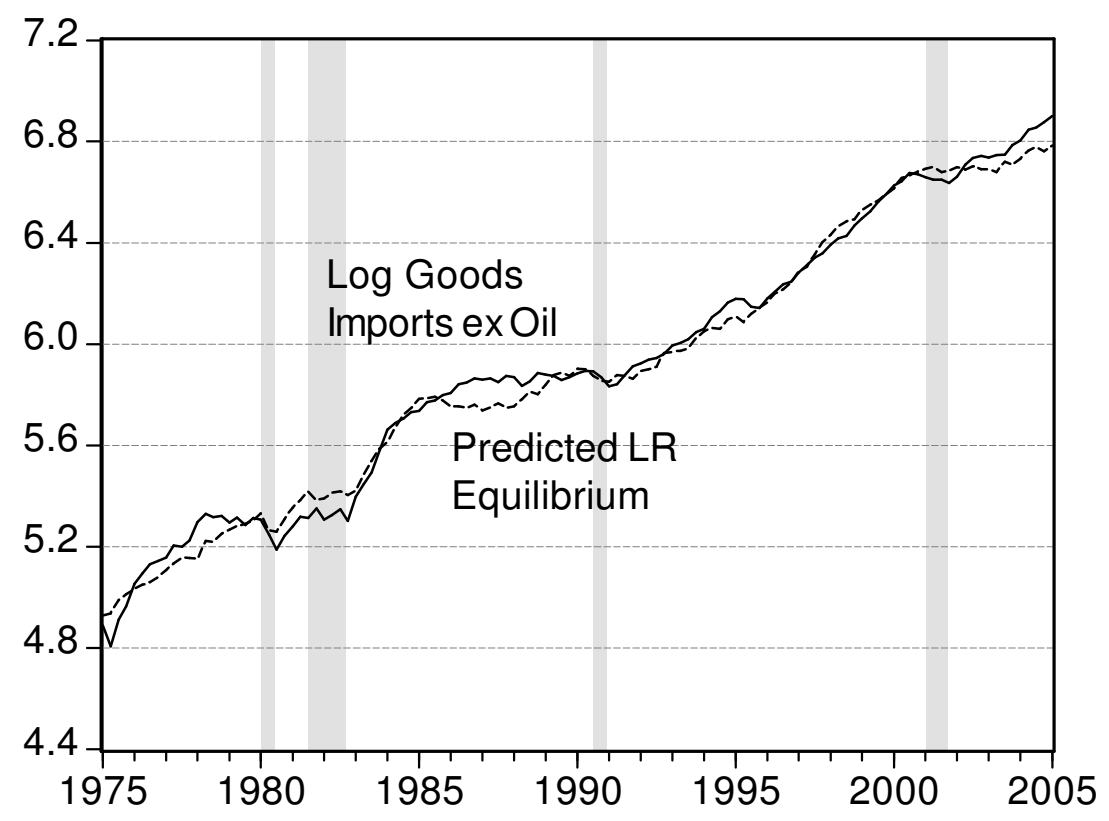

Figure 9: Non-oil Goods Imports and Estimated LR Equilibrium Values. Source: BEA and author's calculations.

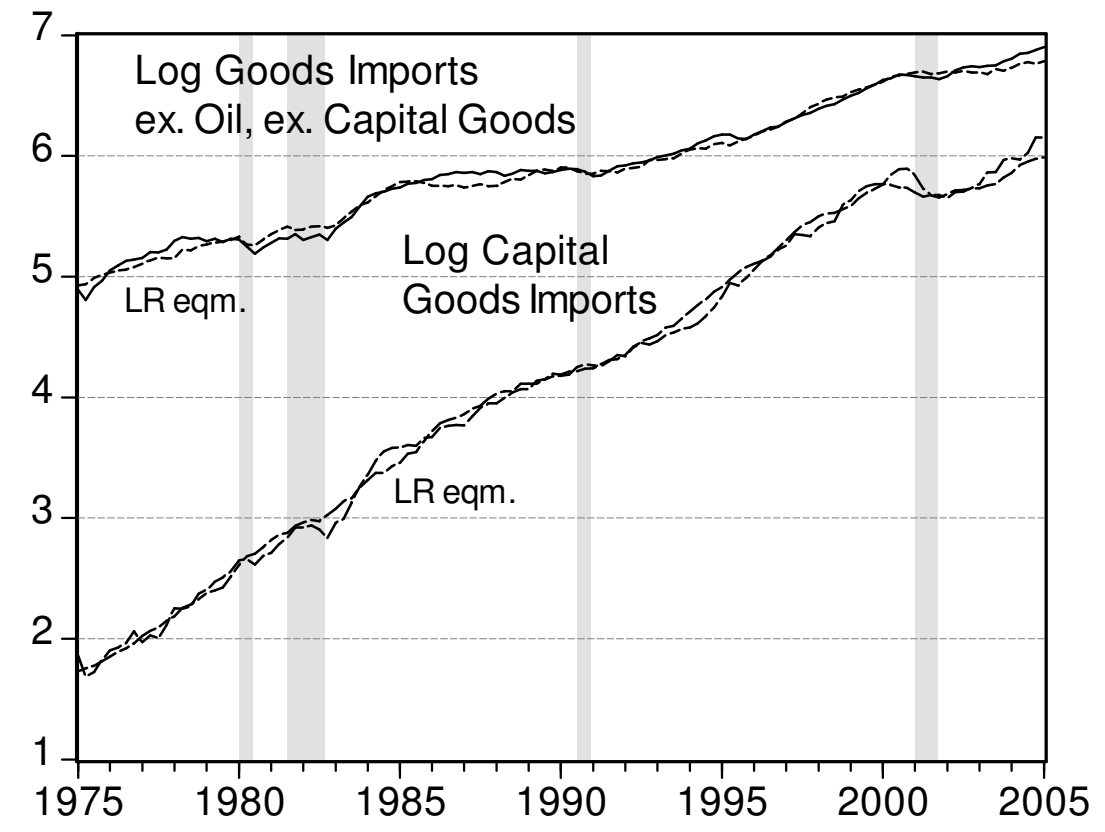

Figure 10: Non-oil, Non-Capital Goods Imports and Estimated Long Run Equilibrium Values. Source: BEA and author's calculations. 


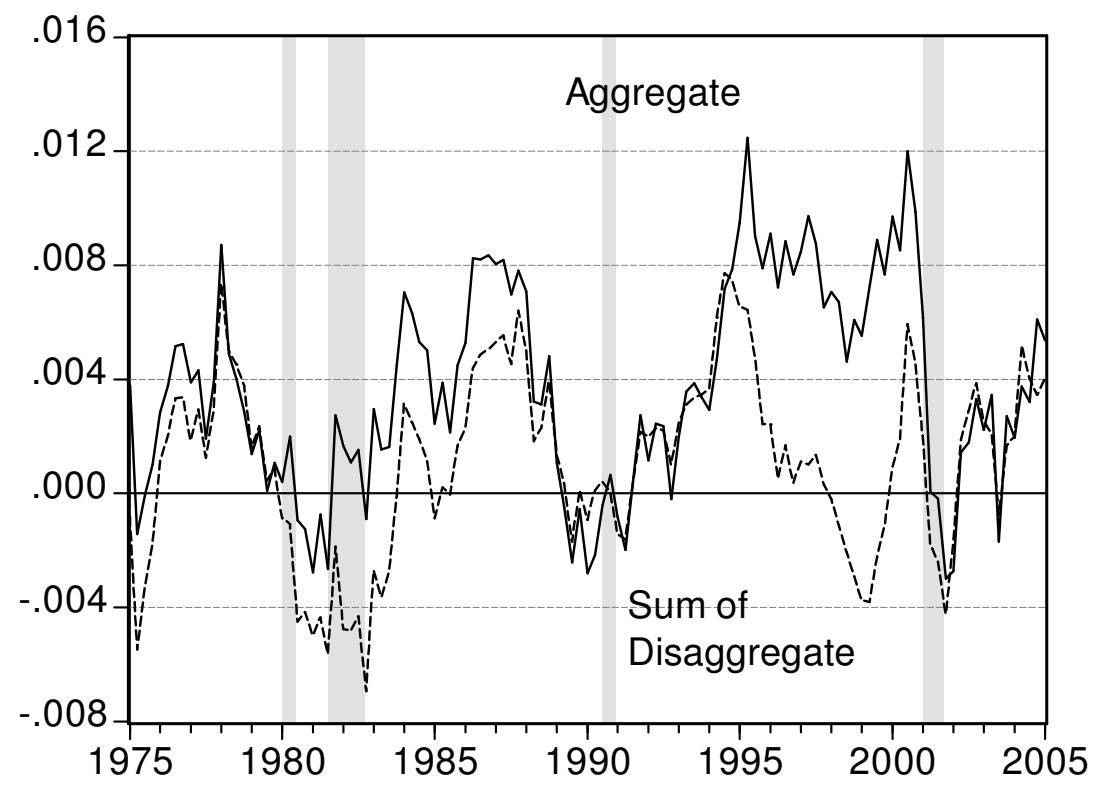

Figure 11: Prediction Error from Aggregate and Sum of Prediction Errors from Disaggregate Components. Source: Author's calculations. 


\section{Appendix 1: Data Sources and Description}

\section{Exchange Rate Indices}

- US "Major currencies" and "broad" trade weighted exchange rate (CPI deflated). Source: Federal Reserve Board website, http://www.federalreserve.gov/releases/h10/Summary/indexnc_m.txt . Weights are listed at http://www.federalreserve.gov/releases/h10/Weights/ . Data accessed August 2005. See Loretan (2005) and Leahy (1998) for details. The economies are Euro area, Canada, China, Japan, Mexico, United Kingdom, Korea, Taiwan, Hong Kong, Malaysia, Singapore, Brazil, Switzerland, Thailand, Australia, Sweden, India, Philippines, Israel, Indonesia, Russia, Saudi Arabia, Chile, Argentina, Colombia, and Venezuela.

\section{Trade Flows, Economic Activity}

- Real and nominal imports and exports of goods and services, and gross domestic product (2000 chain weighted dollars). Source: BEA, July 2005 release.

- Non-computer goods and services, Non-computer, non oil goods imports, calculated using Tornqvist approximation. See Whelan (2000) for an explanation of the procedure.

- Rest-of-World GDP (2000 dollars). U.S. exports weighted rest-of-world GDP. Updated over 2004q4-2005q1 period using the CBO rest-of-world real GDP index (accessed June 2005).

- Industrial production. For US, industrial production, seasonally adjusted. Source: BEA via St. Louis Fed. For rest-of-world, industrial country industrial production, not seasonally adjusted. Source: IFS. X-12 multiplicative factor seasonal adjustment performed on logged index.

\section{Tariffs}

- Tariff rates, average of U.S., Japan and European Union, provided by Kei-Mu Yi, and described in Yi (2003). Annual data interpolated by moving average to create quarterly data. 